\title{
Use of Chosen Methods for Determination of the USLE Soil Erodibility Factor on the Example of Loess Slope
}

\section{Edyta Kruk ${ }^{1}$}

1 Department of Land Reclamation and Environmental Development, Faculty of Environmental Engineering and Land Surveying, University of Agriculture in Krakow, Al. Mickiewicza 24/28, 30-059 Krakow, Poland e-mail: e.kruk@urk.edu.pl

\begin{abstract}
The investigations were carried out on a loess slope in the Brzeźnica village, in the Rudnik commune. Nine points were chosen, in which particular parameters being parts of the examined models, were determined. On the basis of the literature, eight models for the Universal Soil Loss Equation (USLE) erodibility factor determination were designated. The chosen models were the ones proposed by: Wishmeier, Monchareonm, Torii et al. and Walker (all based on texture and organic matter content, Wischmeier and Smith (based on texture organic matter content and additionally on aggregate classes), Wiliams et al. (based on texture and organic carbon content), Renard et al. as well as Stone and Hilborn (both based only on texture). The investigated site was characterized as well. The statistical conclusions were drawn and the obtained results were compared with the results presented in the literature.
\end{abstract}

Keywords: soil erodibility factor, model USLE

\section{INTRODUCTION}

Water erosion, along with salinity [Boron et al. 2010, Boroń et al. 2016, Klatka et al. 2015], drought, floods and heavy metals contamination, belongs to the most dangerous forms of soil degradation. Soil water erosion can be determined in various ways, including modelling, the approach used most often. Among many published soil erosion models, Universal Soil Loss Equation (USLE) is the most popular. One of the factors used in creating this model is the soil erodibility factor, which depends on the mechanical properties of the soil. The main factors determining it are textural properties (granulometry and sorting), structural properties (presence of stable soil aggregates), the void ratio and soil moisture [Klatka 2020]. The USLE erodibility factor $K_{U S L E}$ expresses the mass of eroded soil $\left(\mathrm{Mg} \cdot \mathrm{ha}^{-1}\right)$ from a standard plot per erodibility unit Je $\left(\mathrm{h} \cdot \mathrm{ha}^{-1} \cdot \mathrm{MJ}^{-1} \cdot \mathrm{cm}^{-1}\right)$. A slope of length $22,1 \mathrm{~m}$, width $1.87 \mathrm{~m}$ and $9 \%$ inclination was taken as the standard plot in the USLE model [Wischmeier and Smith 1978], assuming that agricultural practices are conducted along the slope and that there is no plant cover for at least two years prior to measurements. For standard conditions, the coefficients L, S, C and $\mathrm{P}$ are defined as 1 [Wischmeier and Smith 1978]. Determination of the soil erodibility factor $K_{U S L E}$ is problematic due to the number of elements characterizing the soil cover, so various methods have been developed to quantify it. These methods can be divided into direct (field) and indirect approaches (by means of equations and nomograms). As the field investigations that involve installing measurement systems for effluents on test plots are costly and time-consuming, they are sometimes impossible to be carried out on a large scale [Shabani et al. 2014]. In practice, this coefficient is therefore calculated by means of empirical functions (pedotransfer functions), taking into account various parameters. Such functions describe the relationships between the easilymeasurable parameters and the parameters which are more difficult to measure.

Wischmeier presented the first method for determining the $K_{\text {USLE }}$ coefficient in 1977 [Torri et al. 1997, Ryczek et al. 2013a]. The method was 
based on the $0.1-0.002 \mathrm{~mm}$ and $<0.002 \mathrm{~mm}$ fractions and organic matter content. Wischmeier and Smith [1978] introduced a modification of the equation [Chodak et al. 2008, Ryczek et al. 2013a, Panagos et al. 2014] involving water permeability, structure and the $0.1-2 \mathrm{~mm}$ fraction. Monchareon (1982) introduced a nomogram [Bahadur 2009, Ryczek et al. 2013a], and Williams (1984) discussed the organic matter content [Zhang et al. 2008]. Modifications were proposed [Renard et al., 1997; Torri et al., 1997] which reduced the input data only to texture [Drzewiecki and Mularz 2005, Ryczek et al. 2013a, Ryczek et al. 2013b]. Stone and Hilborn [2000] used considerable simplifications concerning the percentage content of organic matter (OM) and soil type. The NRCS [2007] elaborated the method, taking into account the coarse particle content and land use [Ryczek et al. 2013a]. In 2017, Walker [2017] proposed a regression equation that enabled researchers to omit the time-consuming process of determining $K_{U S L E}$ based on the Wischmeier and Smith nomogram [1978]. Some investigations [Vaezi et al. 2010] emphasised that $K_{U S L E}$ may be influenced by soil structure, and is related to calcium carbonate. In calcareous soil, calcium carbonate influences the formation of soil aggregates, causing increased water permeability and consequently a decrease in $K_{\text {USLE }}$ [Shabani et al. 2014]. The $K_{U S L E}$ values calculated for such soils may not be appropriate [Vaezi et al. 2010].

The soil erodibility factor remains the subject of tests and verifications, so despite the extensive literature on the topic, the best method of calculation remains an open question. In Poland, similar investigations were carried out by Ryczek et al. [2013a] among others, within the $48.54 \mathrm{~km}^{2}$ Kasińczanka basin. The authors analysed nine methods for 52 sampling points located within the basin, with soil textures including loam, sandy clay loam, clay loam and silt loam. The organic matter content was between 1.85 and $4.28 \%$, while water permeability was between $0.84 \cdot 10^{-3}$ and $4.87 \cdot 10^{-1} \mathrm{~m} \cdot \mathrm{d}^{-1}$. The following calculation methods were used: Wischmeier [1977], Wischmeier and Smith [1978], Monchareon (1982), Williams et al. (1984), Renard et al. [1997], Torri et al. [1997], and Stone and Hilborn [2000] as well as the NRCS $K_{w}$ and the NRCS $\underline{K}_{f}$ [2007] models. Baryła [2012] carried out the investigations on the soil mass eroded in the area of the Agricultural Farm Puczniew (Łódź province). The arable lands of the farm consist mostly of loam and sand. The $K_{U S L E}$ coefficient was determined by use of the Wischmeier and Smith [1978] nomogram. Święchowicz [2016] investigated the $K_{U S L E}$ factor in the Lazy village located on the Brzesko Foreland, in the area of the Agricultural Pilot Plant of the Jagiellonian University 'Lazy'. The texture was uniform and the sand content was low (below $10 \%)$, with high silt content (50-70\%) and clay content $(8-18 \%)$. The organic matter content in the humus horizon was between 0.5 and $1.6 \%$. Relief was characterised by the occurrence of curved hilltop hummocks with sections of flattened surfaces, and mainly low-gradient $\left(3-10^{\circ}\right)$ concavo-convex slopes.

Kruk [2016] investigated the soil loss in the mountain basin of the Mątny stream, which has an area of $1.47 \mathrm{~km}^{2}$. Soil texture was determined for 47 points, with results showing sandy clay loam, clay loam, loam and silty clay in the study area. The author used the Wischmeier and Smith [1978] and Renard et al. [1997] methods. Ryczek et al. [2013b] carried out investigations in the Smugawka stream basin, located in the Island Beskid region with an area of $5.40 \mathrm{~km}^{2}$. The $\mathrm{K}_{\text {USLE }}$ parameter was determined using the Renard et al. method [1997]. The soils in the basin included clay loam, loam, sandy loam and silty clay. The $\mathrm{K}_{\mathrm{USLE}}$ factor can also be determined by mapping the $\mathrm{K}_{\mathrm{USLE}}$ distribution, as elaborated by Panagos et al. [2014], who determined the $\mathrm{K}_{\text {USLE }}$ based on the Wischmeier and Smith [1978] method for 25 countries including Poland.

The aim of this work was to compare these methods for determination of the soil erodibility factor, $\mathrm{K}_{\mathrm{USLE}}$, for use in the USLE model.

\section{Study site}

The study site was an area located in the province of Silesia, Racibórz administrative district, Rudnik commune. The investigated site is geomorphologically part of the Silesia Plain subprovince, covering all of the western and middle parts of the Racibórz administrative district in the Oder river valley. Two mesoregions occur within the commune, Głubczyce Plateau and Racibórz Valley [Kondracki 2000]. According to the Gumiński agricultural-climatic province categories, the area belongs to the Sub Sudety-XVIII province. Masses of wet air from the Atlantic Ocean reach the area often, with rarer masses of dry continental air from the east. Total rainfall is $650 \mathrm{~mm}$ per year, and there are approximately 40-55 days 
with snow cover each year. The mean yearly temperature is $8.0^{\circ} \mathrm{C}$. The warmest month is July (mean temperature about $18^{\circ} \mathrm{C}$ ), and lowest temperatures are recorded in January (mean $-2 \cdot 1^{\circ} \mathrm{C}$ ). There are typically 30 frosty days and 120 days with ground-frost each year. The growing season starts early, in the second week of March, and lasts an average of 210-220 days. Southern and western winds prevail over the area [Radomski 1987, Woś 1993]. The study site was covered by winter wheat during fieldwork on 20 June 2017. Before sowing, traditional tillage was used.

\section{Methods}

Field experimentation was carried out on 20 June 2017. Nine measuring points were chosen (Fig. 1a). Three replicates for each sample were taken from the upper part of soil, using $100 \mathrm{~cm}^{3}$ rings for determination of physical properties (Fig. 1b) and using plastic bags for the remaining analyses. The following soil properties were analysed: texture by means of the Casagrande method [PN-R-04032 1998], bulk density $\left(\rho_{o}\right)$, solid phase density $\left(\rho_{s}\right)$, total porosity $(n)$ [Mocek et al. 1997, 2015], organic matter content (OM), organic carbon content $(C)$ [Oleksynowa et al. 1991] and saturated hydraulic conductivity $(k)$ [Twardowski and Drożdżak 2006] (Table 1).

The $\mathrm{K}_{\text {USLE }}$ coefficient was calculated using 8 methods, which depend on various soil properties. In this work, the models proposed by Wischmeier [1997], Wischmeier and Smith [1978], Monchareon (1982) [Bahadur 2009], Williams et al. (1984) [Zhang et al. 2008], Renard et al. [1997], Torri et al. [1997], Stone and Hilborn [2000] and Walker [2017] (Table 2) were used. All the results were presented in units of $\mathrm{Mg} \cdot \mathrm{ha} \cdot \mathrm{Je}^{-1}$. The statistical analyses were performed using the Statistica 13.0 software package, using the Least Significant Difference (LSD) test and basic statistical analysis (Tukey and Fischer-Snedecor procedures). The LSD method allowed determining which differences are statistically significant. In the case where the absolute value of the difference between the means is greater than LSD $|\bar{X} i-\bar{X}| \geq N I R$, it is assumed that differences are significant. The LSD values were calculated using the Tukey test, based on the Student $t$-distribution. The mathematical model is described as:

$$
\mathrm{x}_{\mathrm{i}, \mathrm{j}}=\mu+\rho_{\mathrm{i}}+\tau_{\mathrm{j}}+\varepsilon_{\mathrm{i}, \mathrm{j}}
$$

where: $x_{i, j}$ is the hypothetical value of the investigated feature of replicate $i(\mathrm{i}=1,2, \ldots .$. and object $j(j=1,2, \ldots .$.$) ,$

$\mu$ is the state value estimated by the mean of all observations,

$\rho_{i}$ is the block component (influence of affiliation to the $i$-th block),

$\tau_{j}$ is the object component (influence of $j$-th object),

$\varepsilon_{i, j}$ is the random component (error),

$r$ is the number of repetitions (blocks), and

$k$ is the number of factor objects.

The mean value for each group and object mean (from all data), total sum of squares (total variability), total sum of squares between groups (from all data) and sum of squares within each group (intragroup variability) were determined. The F-statistics were then calculated and compared with the table values. The results are presented in Table 3.
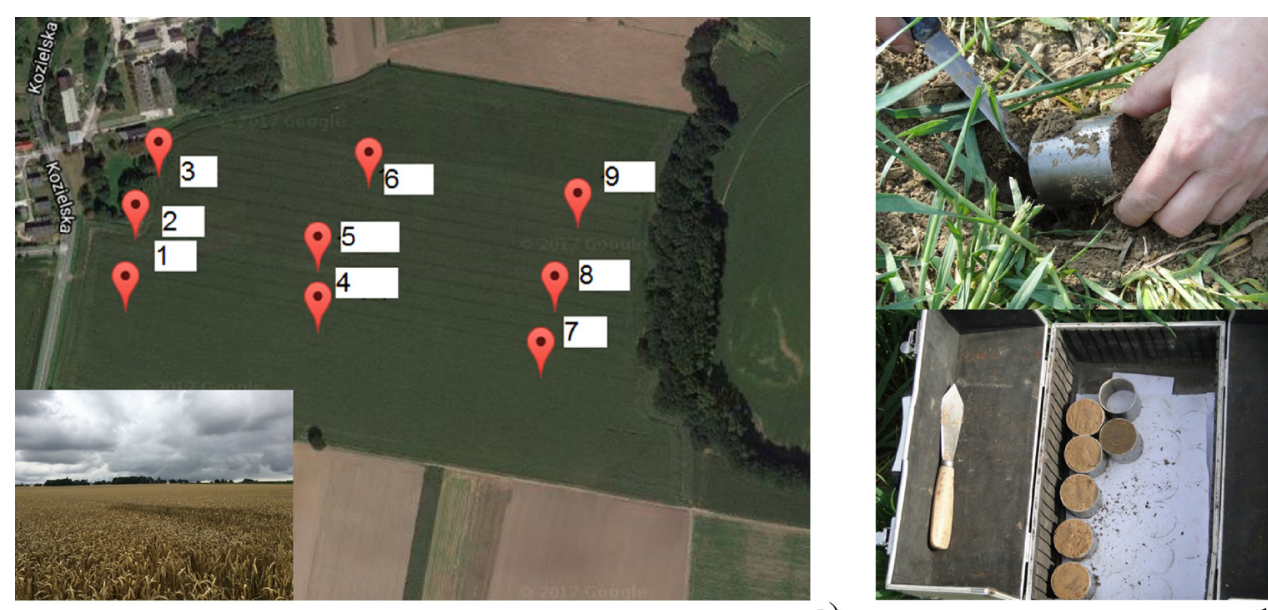

a)

Figure 1. Location of the points measured in the study site 
Table 1. Soil properties

\begin{tabular}{|c|c|c|}
\hline Parameter & \multicolumn{2}{|r|}{ Method } \\
\hline $\begin{array}{l}\text { Bulk density }\left(\rho_{o}\right), \mathrm{Mg} \cdot \mathrm{m}^{-3} \\
\text { Internal ring volume }\left(V_{p}\right), \mathrm{m}^{3}\end{array}$ & $\begin{aligned} \rho_{0} & =\frac{m_{m t}-m_{t}}{V_{p}} \\
V_{p} & =\frac{\pi \cdot d^{2}}{4}\end{aligned}$ & $\begin{array}{l}m_{m t}-\text { dry soil mass with a ring, } \mathrm{Mg} ; m_{t}-\text { mass of a ring, } \\
\mathrm{Mg} \\
d \text {-internal ring diameter, } \mathrm{m}\end{array}$ \\
\hline Solid phase density $\left(\rho_{s}\right), \mathrm{Mg} \cdot \mathrm{m}^{-3}$ & $\rho_{s}=\frac{m_{m t} \cdot \rho_{w}}{P_{w}+g-P_{w \cdot g}}$ & $\begin{array}{l}P_{w}-\text { mass of a picnometer with distilled water, } \mathrm{Mg} \\
P_{w . g}-\text { mass of a picnometer with distilled water and soil, } \\
\mathrm{Mg} \\
\rho_{w}-\text { water density, } \mathrm{Mg} \cdot \mathrm{m}^{-3}\end{array}$ \\
\hline Total porosity $(n),-$ & $n=1-\frac{\rho_{o}}{g_{s}}$ & $\begin{array}{l}\rho_{o}-\text { bulk density, } \mathrm{Mg} \cdot \mathrm{m}^{-3} \\
\rho_{s} \text { - soil phase density, } \mathrm{Mg} \cdot \mathrm{m}^{-3}\end{array}$ \\
\hline \multirow[b]{2}{*}{ Organic matter content, (OM), \% } & \multicolumn{2}{|c|}{$\begin{array}{l}\text { The Turin method [Oleksynowa et al. 1991], depending in oxidation of organic mat- } \\
\text { ter by potassium dichromate }\left(\mathrm{Cr}^{6+}\right) \text {. } \\
\text { Organic matter content was calculated according to the equation: }\end{array}$} \\
\hline & $O M=\frac{(a-b) \cdot f \cdot 0,10344}{q}$ & $\begin{array}{l}a-\text { amount of } 0,2 \mathrm{n} \mathrm{FeSO}_{4} \text { for titration of blind sample, } \\
b-0,2 \mathrm{n} \mathrm{FeSO} \\
f \\
f-\text { amount of } 0,2 \mathrm{n} \mathrm{FeSO} 4 \\
q \text { - mass of dry soil }\end{array}$ \\
\hline Organic carbon content $(C), \%$ & $\% \mathrm{OM}=\% \mathrm{C} \cdot 1,724$ & 1,724 - converting coefficient \\
\hline $\begin{array}{l}\text { Saturated hydraulic conductivity }(k),{\mathrm{m} \cdot \mathrm{d}^{-1}}^{\text {Empirical coefficient, } C}\end{array}$ & $\begin{array}{l}k=C \cdot d_{10}^{2} \\
C=400+40 \cdot(n-26)\end{array}$ & $\begin{array}{l}d_{10}-\text { diameter of particles, that mass with the mass of } \\
\text { lower diameter is } 10 \% \text { of sample mass, } \\
n-\text { total porosity, } \%\end{array}$ \\
\hline
\end{tabular}

The total sum of squares $(G)$ was calculated according to the equation

$$
G=\sum_{i=1}^{a} \sum_{j=1}^{n} y_{i, j}^{2}-\frac{Y_{. .}^{2}}{a n}
$$

the sum of squares of factors $(T)$ was calculated according to the equation

$$
T=\frac{1}{n} \sum_{i=1}^{a} y_{i, j}^{2}-\frac{Y_{. .}^{2}}{a n}
$$

and the sum of block squares $(R)$ was calculated according to the equation

$$
R=\sum_{j=1}^{n} y_{i, j}^{2}-\frac{Y_{. .}^{2}}{a n}
$$

Correction $P$ is calculated according to the equation

$$
\begin{gathered}
P=\frac{Y_{.}^{2}}{a n} \\
Y_{i}=\sum_{j=1}^{n} y_{i j} \\
Y_{j}=\sum_{i=1}^{a} y_{i j}
\end{gathered}
$$

$$
Y_{. .}=\sum_{i=1}^{a} \sum_{j=1}^{n} y_{i j}=\sum_{i=1}^{a} Y_{i}=\sum_{j=1}^{n} Y_{j}
$$

The sum of squared errors $(E)$ is calculated according to the equation

$$
\mathrm{E}=\mathrm{G}-\mathrm{T}-\mathrm{R}
$$

LSD was calculated as a product of the standard deviation of the means difference $s_{D}$ (based on error due to variance) and the $t_{D}$-value of the dependent variable in relation to significance level $\alpha$, degrees of freedom for the error $(v)$ and the number of compared means $(m)$ :

$$
N I R=t(\alpha ; k, N-k) S_{e} \sqrt{\frac{1}{n}}[-]
$$

where: $t(\alpha ; k, N-k)$ is the critical value of the standardised Student t-test range. The standard deviation of the difference between the means was calculated as:

$$
S_{D}=\sqrt{\frac{2 s_{E}^{2}}{r}}[-]
$$

\section{RESULTS AND DISCUSSION}

The soil texture was analysed for 9 sample locations, based on the PN-R-04032 [1998] standard (table 4). The concentrations 
Table 2. Values of the soil erodibility factor $\mathrm{K}_{\mathrm{USLE}}$

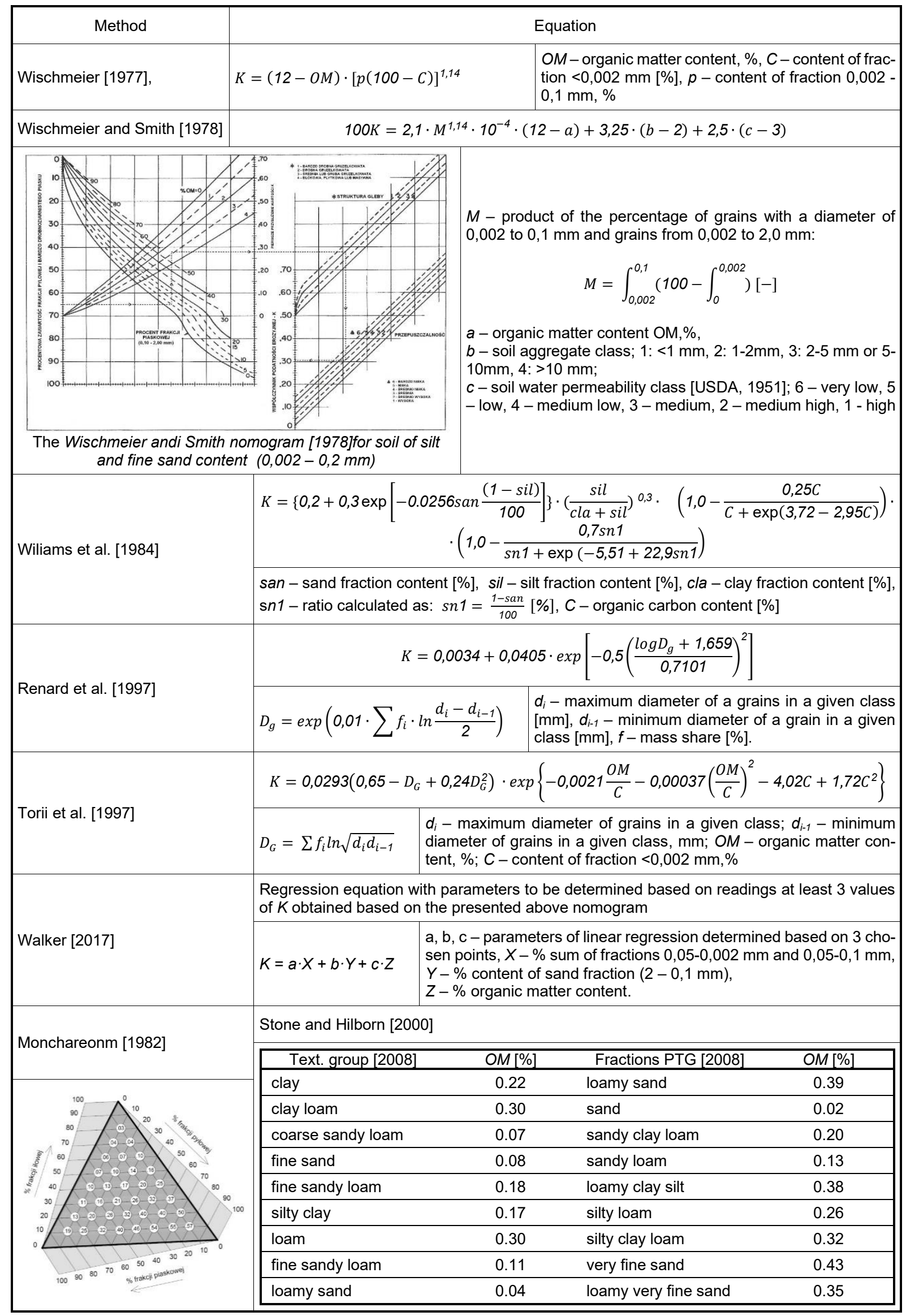


of sand $(2.0-0.05 \mathrm{~mm})$, coarse silt $(0.05-$ $0.02)$, fine silt $(0.02-0.002 \mathrm{~mm})$ and clay $(<0.002 \mathrm{~mm})$ are presented in Table 4 . The classification of granular groups was performed according to the methods of PTG [2008].

The analysis of the results showed that the soils in the study area are not differentiated by texture, but rather are all loamy silt. The sand content was $13-18 \%$, the silt content was $70-79 \%$ and the clay content was $5-12 \%$. Three replicate measurements of bulk density $\left(\rho_{o}\right)$, solid phase density $\left(\rho_{s}\right)$, organic matter content $(O M)$, organic carbon content $(C)$ and total porosity $(n)$ were carried out for each point, with results presented in Table 5. Bulk density $\left(\rho_{o}\right)$ varied between 1.41 and $1.57 \mathrm{Mg} \cdot \mathrm{m}^{-3}$, while solid phase density $\left(\rho_{s}\right)$

Table 3. Analysis of variance [Rudnicki 1992]

\begin{tabular}{|l|c|c|c|c|}
\hline $\begin{array}{l}\text { Source of } \\
\text { variability }\end{array}$ & $\begin{array}{c}\text { Degree of } \\
\text { freedom }\end{array}$ & $\begin{array}{c}\text { Sum of } \\
\text { squares }\end{array}$ & $\begin{array}{c}\text { Mean } \\
\text { squares s }\end{array}$ & \multirow{2}{*}{$\mathrm{F}_{\text {cal }}$} \\
\hline Blocks & $\mathrm{r}-1$ & $\mathrm{R}$ & & \multirow{2}{*}{$s_{T}^{2}$} \\
\cline { 1 - 4 } Factor & $\mathrm{k}-1$ & $\mathrm{~T}$ & $\mathrm{~T} /(\mathrm{k}-1)$ & \multirow{2}{*}{$s_{E}^{2}$} \\
\cline { 1 - 4 } Error & $(\mathrm{r}-1)(\mathrm{k}-1)$ & $\mathrm{E}$ & $\begin{array}{c}\mathrm{E} /[(\mathrm{r}-1) \\
(\mathrm{k}-1)]\end{array}$ & \\
\hline Total & $\mathrm{rk}-1$ & $\mathrm{G}$ & & \\
\hline
\end{tabular}

varied between 2.52 and $2.75 \mathrm{Mg} \cdot \mathrm{m}^{-3} . O M$ varied from 0.85 to $1.35 \%$, and $C$ fell between 0.52 and $0.78 \%$. Total porosity (n) was between 40 and $46 \%$ (table 5).

Saturated hydraulic conductivity varied between 0.003111 and $0.009097 \mathrm{~m} \cdot \mathrm{d}^{-1}$. Saturated hydraulic conductivity plays an important role in forming surface runoff. High values show low surface runoff, while low values indicate higherintensity runoff. Saturated hydraulic conductivity was classified as very low, $k<3.0 \cdot 10^{-5}$ [USDA Soil Survey Manual 1951], in all samples. These results show that high runoff can occur in the study area. Figure 2 shows soil material transported as a result of runoff on the day of field investigations (20 July 2017).

\section{Results of calculations of the $\mathrm{K}_{\text {USLE }}$ soil erodibility factor}

Table 6 presents the values of parameters used to determine the value of $\mathrm{K}_{\mathrm{USLE}}$. For the Wischmeier method [1977], the required percentage content of grains in the size range $0.1-0.002 \mathrm{~mm}$ was determined based on the grain size distribution

Table 4. Soil texture at sampling locations

\begin{tabular}{|c|c|c|c|c|c|}
\hline \multirow{3}{*}{ Point } & \multicolumn{5}{|c|}{$\%$ share of separates of diameter [mm] } \\
\hline & \multirow{2}{*}{$\frac{\text { sand }}{2,00-0,05}$} & \multicolumn{3}{|c|}{ silt } & \multirow{2}{*}{$\begin{array}{c}\text { clay } \\
<0.002\end{array}$} \\
\hline & & $0.05-0,02$ & $0.02-0,005$ & $0.005-0,002$ & \\
\hline 1 & 17 & 40 & 24 & 9 & 10 \\
\hline 2 & 17 & 40 & 25 & 8 & 10 \\
\hline 3 & 18 & 37 & 27 & 6 & 12 \\
\hline 4 & 13 & 41 & 26 & 8 & 12 \\
\hline 5 & 15 & 39 & 25 & 10 & 11 \\
\hline 6 & 15 & 38 & 26 & 10 & 11 \\
\hline 7 & 14 & 40 & 31 & 5 & 10 \\
\hline 8 & 14 & 42 & 29 & 8 & 7 \\
\hline 9 & 16 & 44 & 26 & 9 & 5 \\
\hline
\end{tabular}

Table 5. Bulk density $\left(\rho_{o}\right)$, solid phase density $\left(\rho_{s}\right)$, organic matter content $(O M)$, organic carbon content $(C)$, total porosity $(n)$ and saturated hydraulic conductivity $(k)$

\begin{tabular}{|c|c|c|c|c|c|c|}
\hline Point & $\rho_{\mathrm{o}}\left[\mathrm{Mg} \cdot \mathrm{m}^{-3}\right]$ & $\rho_{\mathrm{s}}\left[\mathrm{Mg} \cdot \mathrm{m}^{-3}\right]$ & $\mathrm{OM}[\%]$ & $\mathrm{C}[\%]$ & $\mathrm{n}[\%]$ & $\mathrm{k}\left(\mathrm{m} \cdot \mathrm{d}^{-1}\right)$ \\
\hline 1 & 1.43 & 2.65 & 1.05 & 0.61 & 46 & 0.004806 \\
\hline 2 & 1.53 & 2.63 & 1.35 & 0.78 & 42 & 0.004132 \\
\hline 3 & 1.45 & 2.58 & 1.05 & 0.61 & 44 & 0.003214 \\
\hline 4 & 1.57 & 2.75 & 0.90 & 0.52 & 43 & 0.003111 \\
\hline 5 & 1.41 & 2.52 & 0.85 & 0.49 & 44 & 0.003635 \\
\hline 6 & 1.57 & 2.72 & 1.15 & 0.67 & 42 & 0.003406 \\
\hline 7 & 1.56 & 2.73 & 1.15 & 0.67 & 43 & 0.004297 \\
\hline 8 & 1.48 & 2.52 & 1.00 & 0.58 & 41 & 0.009097 \\
\hline 9 & 1.52 & 2.53 & 1.05 & 0.61 & 40 & 0.008047 \\
\hline
\end{tabular}


curves. For sample sites $1,2,4$, and 6 , this value was $82 \%$; for site $3,80 \%$; for site $5,81 \%$; for site $7,83 \%$; for site $8,86 \%$; and for site $9,87 \%$. The estimated $K_{U S L E}$ values were $0.27-0.31 \mathrm{t} \cdot \mathrm{ha}^{-1} \cdot \mathrm{Je}^{-1}$. The values of the $2.0-0.1 \mathrm{~mm}$ grain size fraction content for the Wischmeier and Smith method [1978] were $8 \%$ for sites $1-3,5$, and $9,6 \%$ for site 4 , and $7 \%$ for sites $6-8$. The values of the $a$ parameter were between 0.85 and $1.35 \%$; in all samples the value of parameter $b$ was found to be 2 (indicating that aggregates have a fine aggregate structure $(1-2 \mathrm{~mm}))$, and parameter $c$ was found to be 6 (indicating that the ground has very low permeability). The values of the $K_{U S L E}$ parameter were found to be between 0.63 and $0.75 \mathrm{t} \cdot \mathrm{ha}^{-1} \cdot \mathrm{Je}^{-1}$. The values of $K_{U S L E}$ determined based on the Monchareon (1982) method (based on the geometric mean between 3 neighbouring values) were between 0.55 and $0.57 \mathrm{t} \cdot \mathrm{ha}^{-1} \cdot \mathrm{Je}^{-1}$. The $K_{U S L E}$ values determined with the Williams method (1984), taking into account texture, organic matter (OM) and organic carbon content $(C)$, fell between 0.16 and $0.18 \mathrm{t} \cdot \mathrm{ha}^{-1} \cdot \mathrm{Je}^{-1}$. The values of $K_{\text {USLE }}$ calculated using the Renard et al. method [1997] were between 0.41 and $0.43 \mathrm{t} \cdot \mathrm{ha}^{-1} \cdot \mathrm{Je}^{-1}$. In the analysis using the Torri et al. equation [1997], calculations were carried out assuming that the lowest grain size value of separates is $0.000005 \mathrm{~mm}$; the results fell between 0.27 and $0.29 \mathrm{t} \cdot \mathrm{ha}^{-1} \cdot \mathrm{Je}^{-1}$. For the Stone and Hilborn [2000] method, the granular subgroups were distinguished based on the division of mineral deposits into groups and subgroups according to PTG [2008], and it was found that for all 9 points $K_{U S L E}$ equalled 0,41 $\mathrm{t} \cdot \mathrm{ha}^{-1} \cdot \mathrm{Je}^{-1}$. Because of the lack of variability in the calculated results, the distribution isolines were not generated. During determination of the regression equation for the Walker method [2017], 3 random sampling points were chosen $(1,5,9)$. This method produced the equation $K=0.0074 \cdot S$ $+0,0044 \cdot C-0,0925 \cdot O M$, with $K_{U S L E}$ values ranging between 0.52 and $0.58 \mathrm{t} \cdot \mathrm{ha}^{-1} \cdot \mathrm{Je}^{-1}$. According
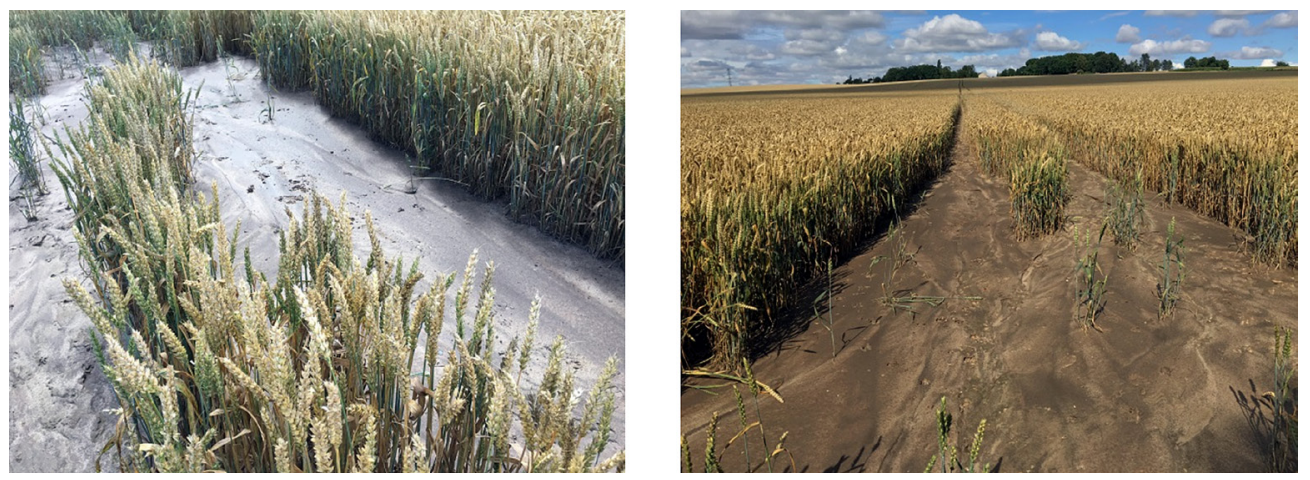

Figure 2. Accumulation of soil material dislocated as a result of runoff

Table 6. $\mathrm{K}_{\mathrm{USLE}}$ determinations for statistical analysis

\begin{tabular}{|c|c|c|c|c|c|c|c|c|}
\hline \multirow{3}{*}{ Point } & \multicolumn{8}{|c|}{ Methods } \\
\hline & A & B & C & D & $\mathrm{F}$ & G & $\mathrm{H}$ & I \\
\hline & $\begin{array}{c}\text { Wischmeier } \\
{[1977]}\end{array}$ & $\begin{array}{c}\text { Wischmeier } \\
\text { and Smith } \\
{[1978]}\end{array}$ & $\begin{array}{c}\text { Monchareonm } \\
\text { [1982] }\end{array}$ & $\begin{array}{l}\text { Wiliams } \\
\text { [1984] }\end{array}$ & $\begin{array}{c}\text { Renard } \\
\text { et al. [1997] }\end{array}$ & $\begin{array}{c}\text { Torii et al. } \\
\text { [1997] }\end{array}$ & $\begin{array}{c}\text { Stone } \\
\text { and Hilborn } \\
{[2000]}\end{array}$ & $\begin{array}{l}\text { Walker } \\
\text { [2017] }\end{array}$ \\
\hline 1 & 0.28 & 0.67 & 0.55 & 0.17 & 0.42 & 0.28 & 0.41 & 0.54 \\
\hline 2 & 0.27 & 0.65 & 0.55 & 0.17 & 0.42 & 0.28 & 0.41 & 0.52 \\
\hline 3 & 0.27 & 0.63 & 0.55 & 0.17 & 0.42 & 0.28 & 0.41 & 0.53 \\
\hline 4 & 0.28 & 0.66 & 0.56 & 0.16 & 0.43 & 0.29 & 0.41 & 0.55 \\
\hline 5 & 0.28 & 0.66 & 0.55 & 0.17 & 0.43 & 0.28 & 0.41 & 0.56 \\
\hline 6 & 0.28 & 0.65 & 0.56 & 0.17 & 0.43 & 0.28 & 0.41 & 0.53 \\
\hline 7 & 0.28 & 0.67 & 0.56 & 0.17 & 0.43 & 0.29 & 0.41 & 0.54 \\
\hline 8 & 0.31 & 0.73 & 0.57 & 0.17 & 0.42 & 0.28 & 0.41 & 0.57 \\
\hline 9 & 0.31 & 0.75 & 0.56 & 0.18 & 0.41 & 0.27 & 0.41 & 0.58 \\
\hline Mean & 0.28 & 0.67 & 0.56 & 0.17 & 0.42 & 0.28 & 0.41 & 0.55 \\
\hline $\begin{array}{l}\text { Mean for } \\
\text { methods }\end{array}$ & & & & 0.4 & & & & \\
\hline Median & & & & 0.4 & & & & \\
\hline
\end{tabular}


to these authors' suggestion, the $K_{U S L E}$ parameters for all 9 sampling locations were recorded based on the Wischmeier and Smith [1978] method. The percentage content of separates with grain sizes $2-0.1$ and $0.1-0.002 \mathrm{~mm}$, and the percentage content of organic matter $(C)$ were used in the first approximation. In order to understand variability in the resulting $K_{U S L E}$ values, a second approximation was made, taking into account soil structure and its permeability (Fig. 3). The results fell between 0.44 and $0.51 \mathrm{t} \cdot \mathrm{ha}^{-1} \cdot \mathrm{Je}^{-1}$ for the first approximation, and between 0.52 and $0.58 \mathrm{t}^{\mathrm{h}} \mathrm{ha}^{-}$ ${ }^{1} \cdot \mathrm{Je}^{-1}$ for the second approximation. The isolines of spatial distribution for the $K_{U S L E}$ values calculated by these methods are presented in Figure 3. The statistical analyses were carried out based on Table 7, which shows the collected results of the $K_{U S L E}$ calculations, with their mean values and object and block sums.

The calculated value of the $F$ coefficient $(2880,000)$ is higher than the value indicated by the Fischer-Snedecor distribution tables $(2,180)$, which suggests that statistically significant differences exist between all the means. The LSDs between the particular methods were calculated using the $q$ Tukey test (Table 8 ). The value of the $q$ Tukey parameter, according to the distribution tables (at $\alpha=0,05 ; v=56 ; m=8$ ) is equal to 4.44 . LSD is equal to 0.02 .

From the LSD analysis results, it was found that the Wischmeier and Smith [1978] method (B) (group $a$ ), based on water permeability, structure and content of the $0.1-2 \mathrm{~mm}$ size fraction, differs statistically significantly from the other methods, as does the Williams (1984) method (D) based on the organic matter content method, among other parameters, belonging to group $e$. The B and D methods should be rejected. The Monchareon (1982) method (C), based on the nomogram with the information on the percentage content of sand, silt and clay separates, and the Walker [2017] method (I), based on the regression equation, make up one group $(b)$ and do not differ statistically. This is similar to the Renard et al. [1997] (F) and Stone and Hilborn [2000] (H) methods which make up group $c$, based on maximum and minimum grain diameters and their mass share (I), percentage organic matter content and soil type information $(\mathrm{H})$. The Wischmeier [1977] method (A) and the Torri et al. [1997] method (G), which together compose group $d$ and are based on the 0.1-0.002 and < $0 ., 002 \mathrm{~mm}$ grain size fractions and organic matter content, do not differ statistically from each other. However, they do differ from the other methods. Methods $\mathrm{F}$ and $\mathrm{H}$ both give the values closest to the mean $\left(0.42 \mathrm{t} \cdot \mathrm{ha}^{-1} \cdot \mathrm{Je}^{-1}\right)$ and median values $\left(0.41 \mathrm{t}^{-} \cdot \mathrm{ha}^{-1} \cdot \mathrm{Je}^{-1}\right)$, and thus can be taken as most reliable. This study was carried out on a low-inclination slope with uniform soil texture, and the site was covered by uniform plants and consisted of arable land; it can be therefore assumed that disagreement due to random factors was reduced to a minimum.

Comparing the obtained results with the values from the literature, one can see that Ryczek et al. [2013a] obtained the values in the range $0.072-0.253 \mathrm{Mg} \cdot \mathrm{ha}^{-\mathrm{Je}^{-1}}$ using the Wischmeier [1977] method; $0.160-0.520 \mathrm{Mg} \cdot \mathrm{ha} \cdot \mathrm{Je}^{-1}$ using the Wischmeier and Smith [1978] method; 0.140$0.560 \mathrm{Mg} \cdot \mathrm{ha}^{\mathrm{J}} \mathrm{Je}^{-1}$ using the Monchareon [1982] method; 0.097-0.196 Mg $\cdot \mathrm{ha}^{\mathrm{Je}} \mathrm{Je}^{-1}$ using the Williams etal. [1984] method; $0.092-0.439 \mathrm{Mg} \cdot \mathrm{ha} \cdot \mathrm{Je}^{-1}$ using the Renard et al. [1997] method; 0.091$0.285 \mathrm{Mg} \cdot \mathrm{ha} \cdot \mathrm{Je}^{-1}$ using the Torri et al. [1997] method; and $0.099-0.412 \mathrm{Mg} \cdot \mathrm{ha} \cdot \mathrm{Je}^{-1}$ using the Stone and Hilborn [2000] method. Baryła [2012] used the Wischmeier and Smith [1978] method to obtain a $K_{\text {USLE }}$ value of $0.390 \mathrm{t} \cdot \mathrm{ha}^{-1} \cdot \mathrm{Je}^{-1}$. Ryczek et al. [2013] used the Renard et al. [1997] method for the Smugawka stream basin and obtained the values of $0.141-0.430 \mathrm{Mg} \cdot \mathrm{ha} \cdot \mathrm{Je}^{-1}\left(0.141 \mathrm{Mg} \cdot \mathrm{ha} \cdot \mathrm{Je}^{-1}\right.$ for clay loam, $0.430 \mathrm{Mg} \cdot \mathrm{ha} \cdot \mathrm{Je}^{-1}$ for silty clay, $0.354 \mathrm{Mg} \cdot \mathrm{ha}^{\mathrm{J}} \mathrm{Je}^{-1}$ for light loam, $0.279 \mathrm{Mg} \cdot \mathrm{ha} \cdot \mathrm{Je}^{-1}$ for sandy clay loam and $0.248 \mathrm{Mg} \cdot \mathrm{ha} \cdot \mathrm{Je}^{-1}$ for loam). Święchowicz [2016] obtained a mean value of $0.377 \mathrm{Mg} \cdot \mathrm{ha}^{-1} \cdot \mathrm{Je}^{-1}$ from direct measurements, and a value of $0.738 \mathrm{Mg} \cdot \mathrm{ha}^{-1} \cdot \mathrm{Je}^{-1}$ by

Table 7. Analysis of variability F $(0.05 ; 7 ; 56)$

\begin{tabular}{|c|c|c|c|c|c|}
\hline \multirow{2}{*}{ Source of variability } & \multirow{2}{*}{ Degree of freedom } & \multirow{2}{*}{ Sum of squares } & \multirow{2}{*}{ Mean squares $\mathrm{s}^{2}$} & \multirow{2}{*}{$\mathrm{F}_{\text {cal }}$} & $\mathrm{F}_{\mathrm{tab}}$ \\
\hline & & & & & $\alpha=0,05$ \\
\hline Blocks & 8 & 0.01 & & \multirow{3}{*}{2880.000} & \multirow{3}{*}{2.180} \\
\hline Method & 7 & 3.60 & 0.514286 & & \\
\hline Random error & 56 & 0.01 & 0.000179 & & \\
\hline Total & 72 & 1.82 & & & \\
\hline
\end{tabular}


means of the Wischmeier and Smith [1978] method. Kruk [2016] carried out investigations in the Mątny stream basin, obtaining the $K_{\text {USLE }}$ values of $0.14-0.57 \mathrm{Mg} \cdot \mathrm{ha}^{-1} \cdot \mathrm{Je}^{-1}$ using the Wischmeier and Smith [1978] method, and the $K_{U S L E}$ values of $0.19-0.44 \mathrm{Mg} \cdot \mathrm{ha}^{-1} \cdot \mathrm{Je}^{-1}$ using the Renard et al. [1997] method. Lower values of $\mathrm{K}_{\mathrm{USLE}}$ using the first method $\left(0.14-0.26 \mathrm{Mg} \cdot \mathrm{ha}^{-1} \cdot \mathrm{Je}^{-1}\right)$ were due to sandy clay loam and clay loam $\left(0.17 \mathrm{Mg} \cdot \mathrm{ha}^{-}\right.$ $\left.{ }^{1} \cdot \mathrm{Je}^{-1}\right)$. For loam, the values fall within the range $0.27-0.52 \mathrm{Mg} \cdot \mathrm{ha}^{-1} \cdot \mathrm{Je}^{-1}$; values $>0.52 \mathrm{Mg} \cdot \mathrm{ha}^{-}$ ${ }^{1} \cdot \mathrm{Je}^{-1}$ were obtained mostly from silty clay. Lower values $\left(\leq 0.41 \mathrm{Mg} \cdot \mathrm{ha}^{-1} \cdot \mathrm{Je}^{-1}\right)$ obtained using the second method were mainly from sandy clay loam and loam. The values $>0.41 \mathrm{Mg} \cdot \mathrm{ha}^{-1} \cdot \mathrm{Je}^{-1}$ almost all occurred in silty clay.

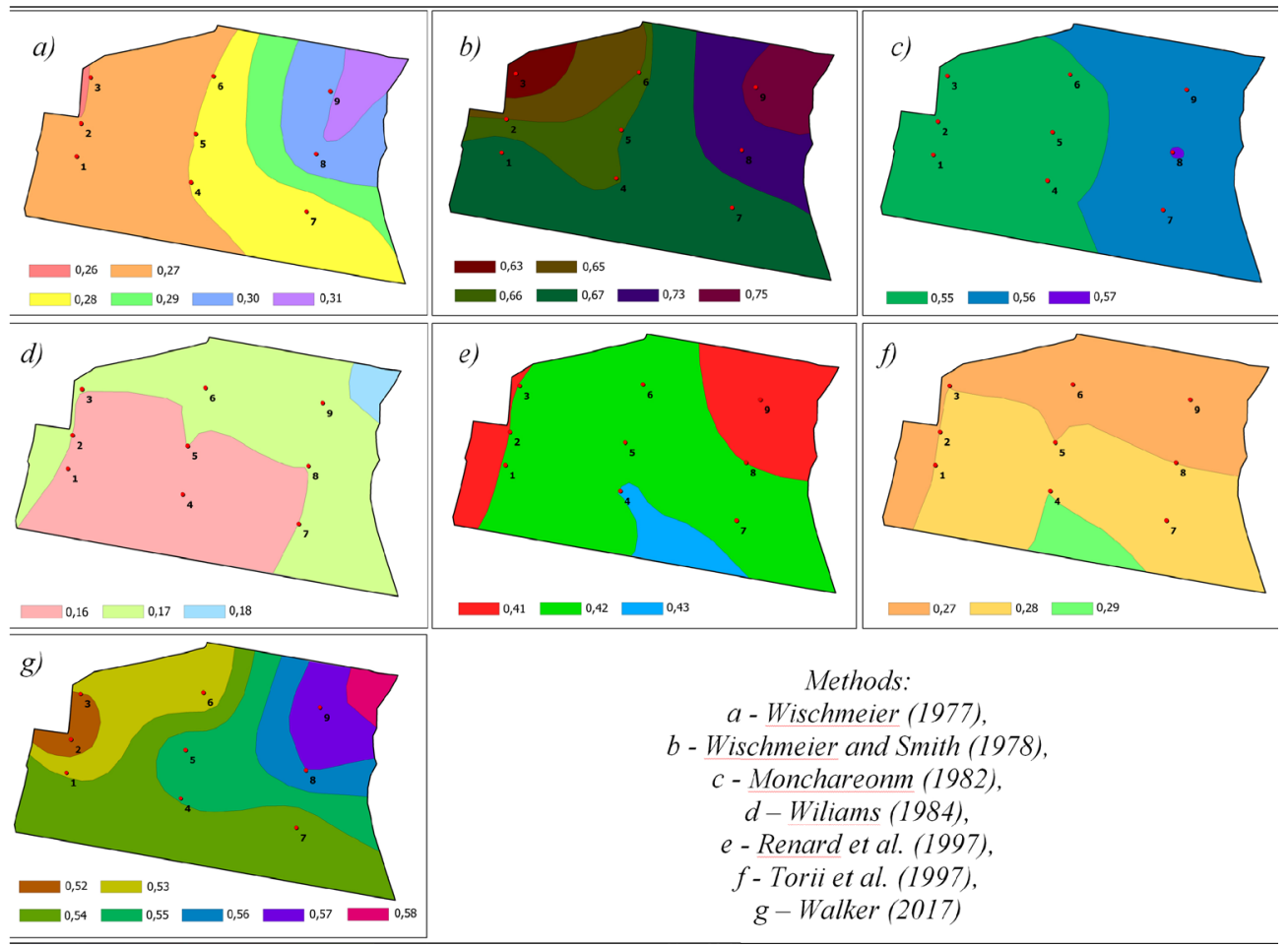

Figure 3. Isolines of the $\mathrm{K}_{\mathrm{USLE}}$ distribution calculated according to the following methods: $a$ - Wischmeier, $b$ - Wischmeier and Smith, $c$ - Monchareon, $d$-Williams, $e$ - Renard et al., $f$ - Torri et al., and $g-$ Walker

Table 8. List of means in decreasing order (triangle of differences between means)

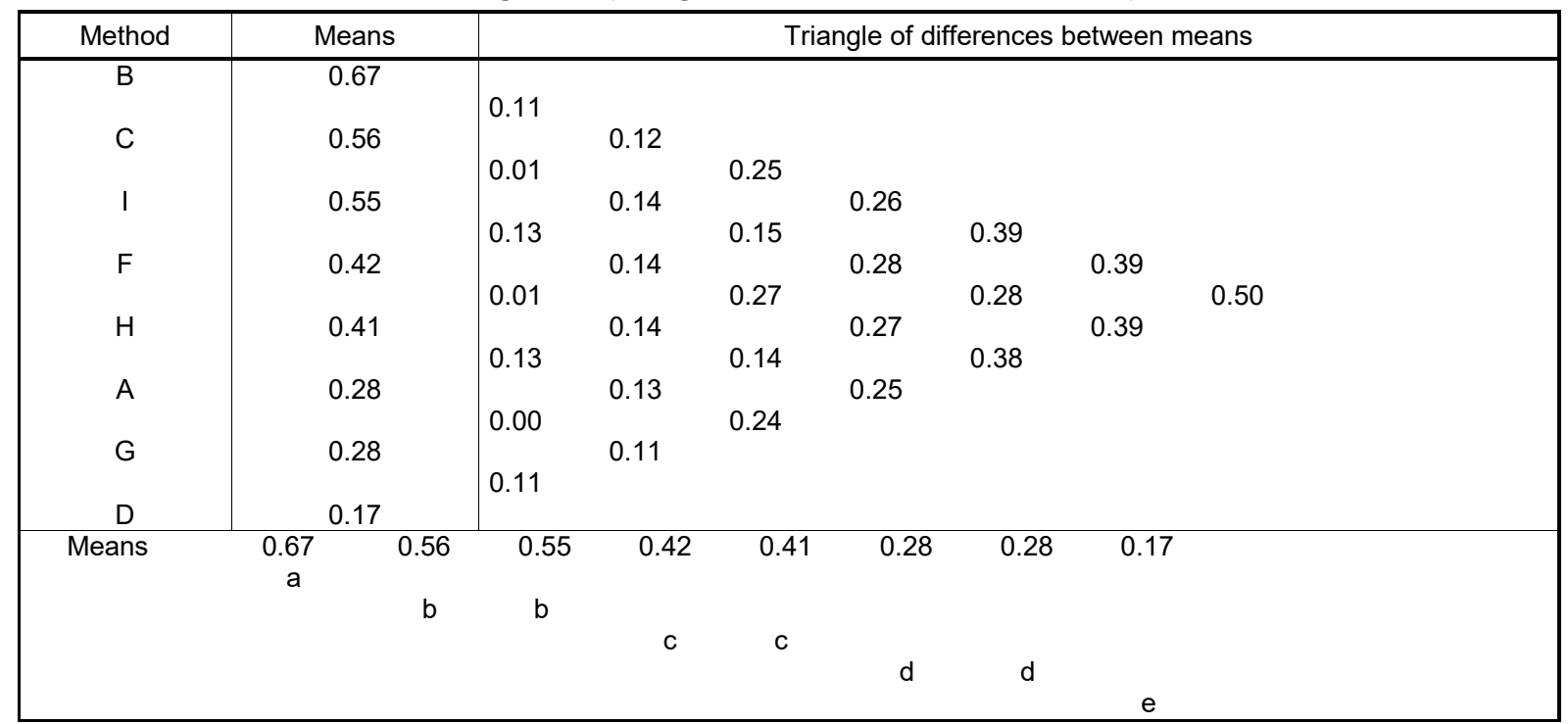

a-e - uniform groups 
The map of $\mathrm{K}_{\mathrm{USLE}}$ factor distributions across Europe produced by Panagos et al. [2014], based on the Wischmeier and Smith [1978] method, shows that the mean $K_{\text {USLE }}$ values for Europe averaged $0.320 \mathrm{Mg} \cdot \mathrm{ha}^{-1} \cdot \mathrm{Je}^{-1}$. The mean value for Poland was $0.299 \mathrm{Mg} \cdot \mathrm{ha}^{-1} \cdot \mathrm{Je}^{-1}$. For the Brzeźnica village, this value was between 0.46 and $0.55 \mathrm{Mg} \cdot \mathrm{ha}^{-1} \cdot \mathrm{Je}^{-1}$.

\section{CONCLUSIONS}

Different methods of calculating the USLE soil erodibility factory $\left(K_{U S L E}\right)$ produce differing results. The maps of the $K_{U S L E}$ distribution indicate that this coefficient shows high spatial variability. The proper determination of the $K_{\text {USLE }}$ coefficient is a very real, complicated and important problem. Detailed statistical analysis of the results obtained with various methods showed noticeable differences between the results calculated by means of the Wischmeier and Smith, and Williams methods, and between the Wischmeier, and Torri et al. methods. The Wischmeier and Smith method gives overly high values, while the Williams, Wischmeier and Torri et al. methods give lower values in comparison to other ones. They should be used in limited contexts. The most reliable methods are the ones proposed by Renard et al., and Stone and Hilborn, because they give the values that fall within the ranges of mean and median values obtained for all the methods.

\section{REFERENCES}

1. Bahadur K.C.K. 2009. Mapping soil erosion susceptibility using remote sensing and GIS: A case of the Upper Nam Wa Watersched, Nan Province, Thailand. Environmental Geology, 57(3), 695-705

2. Baryła A. 2012. Estimating the loss of soil At different probabilities of erosive rainfalls - a case study of experimental farm in Puczniew (in Polish). Woda - Środowisko - Obszary Wiejskie, 12, 4(40), 7-16.

3. Boroń K., Klatka S., Ryczek M., Liszka P. 2016. The formation of the physical, physico-chemical and water properties reclaimed and not reclaimed sediment reservoir of the former Cracow Soda Plant "Solvay" (in Polish). Acta Scientiarum Polonorum Formatio Circumiectus, 15(3), 35-43.

4. Boroń K., Klatka S., Ryczek M., Zając E. 2010. Reclamation and cultivation of Cracow soda plant lagoons (in Polish). In: Construction for Sustainable Environment. Sarsby \& Meggyes, CRC Press Taylor
\& Francis Group London, A Balkema, 245-250.

5. Chodak T., Tasz W., Kaszubkiewicz J. 2008. An attempt to estimate and verify the USLE model In the area of a single slope and agricultural microcatchment (in Polish). Materiały Konferencji, Polanica Zdrój.

6. Drzewiecki W., Mularz S. 2005. Model USPED as a tool for assessment of soil erosion and deposition effect) (in Polish). Rocz. Geomat., Tom III, z. 2, 5-9.

7. Klatka, S. T. 2020. Soil Productivity Index in the Selected Area of Post-Mining Geomechanical Deformations. Journal of Ecological Engineering, 21(5), 148-154. https://doi. org/10.12911/22998993/122514

8. Klatka S., Malec M., Ryczek M., Boroń K. 2015. Influence of mine activity of the coal mine "Ruch Borynia" on water management of chosen soils on mining area (in Polish). Acta Scientiarum Polonorum Formatio Circumiectus, 14 (1), 115-125.

9. Kruk E. 2016. Determination of the probabilisty of ravine erosion with the use of selected topographic parameters of a mountains catchment In the ArcGIS software (in Polish). In: Szałata Ł., Doskocz J., Kardasz P. (Eds.) Innowacje w polskiej nauce w obszarze life science i ochrony środowiska: Przegląd aktualnej tematyki badawczej. Wydawnictwo Nauka i Biznes, 106-117.

10. Kondracki J. 2000. Regional geography of Poland (in Polish). Wydanie drugie poprawione, PWN, Warszawa.

11. Mocek A., Drzymała S., Maszner P. 1997. Genesis analysis and classification of soils (in Polish). Wyd. Akademii Rolniczej w Poznaniu.

12. Mocek A. 2015. Soil science (in Polish). Wydawnictwo Naukowe PWN, Warszawa.

13. NRCS (National Resources Conservation Service). 2007. Part 618 - Soil Properties and Qualities. US Department of Agriculture, http://soil.usda.gov/ technical/handbook/contents/part618.html\#55.

14. Oleksynowa K., Tokaj J., Jakubiec J. 1991. Guide to exercies in soil science and geology (in Polish). Wydawnictwo AR, Kraków.

15. Panagos P., Meusburger K., Ballabio C., Borrelli P., Alewell C. 2014. Soil erodibility in Europe: A highresolution dataset based on LUCAS. Science of the Total Environment 479-480, 189-200.

16. PN-R-04032. 1998. Soil and mineral soil materials - Sampling and determination of the grain size composition (in Polish).

17. Polskie Towarzystwo Gleboznawcze. 2008. Classification of soil and mineral formation (in Polish).

18. Radomski C. 1987. Agrometeorology (in Polish). PWN, Warszawa.

19. Renard K.G., Foster G.R., Weesies G.A, McCool D.K., Yoder D.C. 1997. Predicting Soil Erosion by 
Water: A Guide to Conservation Planning with the Revised Universal Soil Loss Equation (RUSLE). Agriculture Handbook, US Department of Agriculture, Washington, DC, 73, pp. 251.

20. Rudnicki F. 1992. Agricultural experimental (in Polish). Wydawnictwo ATR, Bydgoszcz, pp. 210.

21. Ryczek M., Kruk E., Boroń K., Klatka S., Stabryła J. 2013a. Comparison of methods for determination of soil erodibility factor (k-usle) on the example of the Kasińczanka stream basin. Acta Scientiarum Polonorum Formatio Circumiectus 12, 2, 103-110.

22. Ryczek M., Kruk E., Malec M., Klatka S. 2013b. Estimation of water erosion threat of the Smuga stream basin in the Beskid Wyspowy. Ochrona Środowiska i Zasobów Naturalnych 24, 4, 33-37.

23. Shabani F., Kumar L., Esmaeili A., 2014. Improvement to the prediction of the USLE K factor, Geomorphology 204, 229-234.

24. Stone R.P., Hilborn D., 2000. Universal soil loss equation (USLE). Ontario: Min. Agricult. Food Rural Affairs: 1-9.

25. Święchowicz, J. 2016. Susceptibility to water erosion soils derived from less-like depo sits (Brzesko Poreland), Southern Poland (in Polish). In: J. Święchowicz \& A. Michno (Eds.), Wybrane zagadnienia geomorfologii eolicznej: Monografia dedykowana dr hab. Bogdanie Izmaiłow w 44. rocznicę pracy naukowej. Instytut Geografii i Gospodarki Przestrzennej UJ Kraków, pp. 331-366.

26. Torri D., Poesen J., Borselli L. 1997. Predictability and uncertainty of the soil erodibility factor using a global dataset. Elsevier Science B.V., 7-10.

27. Twardowski K., Drożdżak R. 2006. Indirect methods of estimating hydraulic properties of grounds (in Polish). Wiertnictwo Nafta Gaz, 23/1, 477-486.

28. USDA. 1951. Soil Survey Manual U.S. Department of Agriculture Handbook 18. US Department of Agriculture, Soil Conservation Staff, U.S. Government Printing Office, Wash. D.C.

29. 2Walker S.J. 2017. An alternative methods for deriving a USLE nomograph $\mathrm{K}$ factor equation. 22nd International Congress on Modelling and Simulation, Hobart, Tasmania, Australia, 3 to 8 December 2017, 964-970.

30. Wischmeier W.H. 1977. Soil erodibility by rainfall and runoff. In: Toy T.J. (Ed.) Erosion: Research techniques, erodibility and sediment delivery. GEO Abstracts, Lid., Norwich, England, 45-56.

31. Wischmeier W.H., Smith D D. 1978. Predicting Rainfall erosion losses - a guide to conservation planning. Supersedes Agriculture Handbook No. 282; Washington, 4-11.

32. Woś A. 1993. Climatic regions of Poland In the light of the frequency of various weathers types (in Polish). Zeszyty Instytutu Geografii i Przestrzennego Zagospodarowania, PAN, 20.

33. Vaezi A.R, Bahrami H.A., Sadeghi S.H.R, Mahdian M.H. 2010. Spatial Variability of Soil Erodibility Factor (K) of the USLE in North West of Iran. J. Agr. Sci. Tech. 12, 241-252.

34. Zhang C., Liu S., Fang J., Tan K. 2008. Research on the spatial variability of soil moisture based on GIS. The International Federation for Information Processing, 258, Computer and Computing Technologies in Agriculture, 1, 719-727. 